\title{
Literature: A Step in the Right Direction
}

\author{
Noela McNamara \\ James Cook University, Cairns
}

\begin{abstract}
Literature offers the opportunity to encounter worlds beyond one's own circumstances, environment, and situation. As an intercultural phenomenon, literary critique and analysis without borders can only be achieved by recognising cultural borders. Reading the literature of different cultures opens literary discourses to cross-cultural dialogue, but for too long, the lack of Indigenous literature within Australian literary discourses stymied the social potential of this intercultural phenomenon. Pressure from the global literary community has necessitated a vast shift of white consciousness to actively embrace narratives of different cultural dimensions, and novels that highlight cultural borders have become a key feature of Australian literature. Invisible literary borders have become apparent through exposure to the once silent voices that now emphasise messages of difference. Indigenous writers including Alexis Wright, Sally Morgan, Kim Scott, Jackie Huggins, Anita Heiss, Larissa Behrendt and Alice Nannup have opened reader consciousness to a broad scope of Indigenous perspectives. Within the arena of literary theories, the writer, reader and novels themselves have all had moments of glory, and while particular texts or authors have been immortalised, others have slipped into oblivion. Through the first person narrative of a non-Indigenous woman, this paper reveals how an intercultural literary experience revealed the restrictions of standard literary critique practices and inspired the creation of a relational discourse to engage with Indigenous voices as part of a methodological process. This intercultural literary process has the potential to inspire cultural awareness through acceptance and understanding of difference to overcome cultural unconsciousness. Such development has the capacity to destabilise invisible borders embedding lasting change in the consciousness of Australian readers and provide a foundational and fundamental step toward sustainable outcomes for Indigenous people.
\end{abstract}

$\mathrm{L}$ iterature may only be a small step in the right direction to foster a society where all people are considered equal, but it is one step on a journey that has the potential to expose and cross literary borders, and one that is growing in momentum. Stories, whether oral or written, based on memory or fact or as a construct of the literary imagination, have always been a fundamental part of the social fabric of communities around the world. As well as educating and entertaining, literature enables people to explore who they are, where they come from, as well as allowing them to imagine other worlds. Socially and politically, however, literature has created borders around and between different cultures.

Through the use of a first person narrative, this paper highlights the potential of literature and literary research to play a powerful role in helping to overcome a subliminal cultural unconsciousness developed through stereotypical negative images of Indigenous people; 
images which influence notions of human equality. Linda Smith (2003, p. 2) states that "both the formal scholarly pursuits of knowledge and the informal, imaginative, anecdotal constructions of the Other are intertwined with each other and with the activity of research [and]...the Other has been constituted with a name, a face, a particular identity, namely indigenous peoples”. A growing awareness and respect for the cultures, knowledge and world views of Indigenous people globally exposes the need for new pathways for researching literature as an intercultural phenomenon to provide opportunities to improve cross-cultural relations globally and personally.

With a view to encouraging debate that will broaden the scope and popularity of Indigenous Australian literature, this paper explores the notion of research without borders through a first person narrative of coming to recognise the potential and power of literature as a catalyst for crossing subliminal borders. This individual experience is inconsequential except in the context of its deconstruction of a journey that exposes how the power of literature (i.e. written or spoken stories) delivered through an alternative cultural lens can inform and/or transform epistemological notions of equity and equality established through ingrained perceptions and via a white lens. This journey inspired the creation of a relational discourse as part of a methodological process to engage with Indigenous voices in literary critique and analysis.

To begin this journey, it is necessary to examine the definition of a literary border. The dictionary refers to a border as "an edge or boundary" (Moore, 2002, p. 117). Physical, metaphysical, religious, cultural, geographical, national, international, gender, race, class, and age are just some of the obvious edges and boundaries that exist within and around all facets of literature, be it writing, reading, and/or critiquing/analysing on a personal or institutional basis. My interest in literature as an intercultural phenomenon centres on the premise that long term uncensored negative stereotypical representation of Indigenous people has helped to nurture a subliminal border between Indigenous and non-Indigenous people in the consciousness of generations of Australian readers. Such representation is demonstrated in Australian literature through seminal reading within the literary discourses in texts including Katharine Prichard's Coonardoo (1929), Patrick White's Voss (1957) and A Fringe of Leaves (1976), Thomas Keneally's The Chant of Jimmy Blacksmith (1972), and Elizabeth O’Connor's Spirit Man (1980). Larissa Behrendt (2004, p. 247) suggests that the misperceptions and mistreatment that Aboriginal women face today is a legacy perpetuated in literature through a colonial discourse:

The ways in which stories in popular culture portray Aboriginal women - the stereotypes that are generated about us - can find their way into legal analysis in a way that sees those stereotypes reinforced and our rights unprotected. It is not just overtly racist literature that provides these examples; they can be just as prevalent in accounts that purport to be sympathetic to Indigenous women. (p. 247)

Despite illumination in history, literary and public discourses since the 1970s of previously undisclosed historical facts concerning the settlement process that created a subliminal cultural border and previously justified notions of the inequality of Indigenous people (unconsciously at least), inequity remains invisible to many people and the parameters and power relations thereof remain unquestioned. While literary discourses today ostensibly profess cultural awareness and literary theories claim that all races are equal and condemn racism, prize-winning contemporary Australian novels continue to reproduce negative stereotypical images of Aboriginal people (Bird, 2002). Texts like Journey to the Stone Age 
(2003), The Secret River (2005) and The Ballad of Desmond Kale (2006), winners of prestigious awards, are products of the literary imagination of some of Australia's most esteemed and popular writers. However, even though some writers profess their stories seek to re-present historical events in settings that enlighten readers to some of the harsh realities of white settlement, their narrative endeavours to bring this plan to fruition through renewed negative stereotypical re-presentations of the settlement era remain questionable (McNamara, 2010, p. 32).

The use of a colonial discourse drawn from incomplete historical records and described only from the perspective and through the voice of white historians artfully conceals the subliminal border that exists in the consciousness of many Australian readers between the life-world of Aboriginal people and the perceived 'norm' of white society. As Kuttainen (2010, p.153-169) suggests, rather than analysing the ways historical fictions seek to undermine settler authority, analysing the ways narrative reinventions may in fact reinforce settler dominance by merely pretending to call it into question might be more productive.

To gain awareness of this subliminal narrative cultural border, it is necessary to read the literature of Indigenous writers who provide glimpses of different cultures, even insights into the life-worlds of other cultures. Such awareness broadens understanding, encourages debate, and stimulates action on research. Indigenous writer Kim Scott, two times winner of Australia’s highest literary award, says his novel That Dead Man Dance (2010) was:

'inspired' by history because, rather than write an account of historical events or Noongar individuals with whom I was particularly intrigued, I wanted to build a story from their confidence, their inclusiveness and sense of play, and their readiness to appropriate new cultural forms - language and songs, guns and boats - as soon as they became available. Believing themselves manifestations of a spirit of place impossible to conquer they appreciated reciprocity and the nuances of cross-cultural exchange.

Unfortunately, as history reveals, notions of reciprocity and nuances of cross-cultural exchange were perceived by the colonisers through a different cultural lens with tragic consequences (Reynolds 1981, 1989, 1999, 2005; Hinkson \& Beckett 2008). Jackie Huggins (1998, p.24) informs that "A new phenomenon of contemporary Aboriginal writing is emerging whereby women writers have the double advantage of relating their history in literally black and white terms, and simultaneously transcending and cutting across cultural boundaries”. I argue that such creations form an invaluable source of vital and critical information about Indigenous life from an intercultural perspective for all readers and should therefore become seminal texts within literary and other discourses.

Indigenous publications are now becoming more prolific, but the dominance of western texts in educational institutions has meant that generations of Indigenous school children, from their first reading experiences, have been forced to read the literature of another culture, i.e. Anglo-Australia. By comparison, as a white Australian, my first experience of Indigenous literature was reading the poetry of Oodgeroo Noonuccal in year 10 at high school, when I was 15 and Oodgeroo was known as Kath Walker. At 15, although Oodgeroo's poetry became a personal favourite, my literary experience was focused through a purely 'white' lens. This lens was limited: firstly, through the perspectives of a 'white' teacher; and secondly, through the limited imagination of a 15 year old 'white' girl without any connection to, or engagement with, Indigenous people. It was not until I enrolled as a mature 
age student in the School of Indigenous Australian Studies to pursue my interest in Indigenous literature that I began to see the poems of Kath Walker as part of the life journey of an Aboriginal woman - Oodgeroo Noonuccal (Walker 1981).

During this period and in a non-academic space, I was fortunate enough to meet, and become good friends with an Aboriginal woman who, as our friendship grew, introduced me to her mother's book. My good friend is the daughter of Alice Nannup, an Aboriginal woman of the Yindjibarndi people from the Pilbara region of Western Australia, whose autobiographical narrative is When the Pelican Laughed (1992). I came to this book feeling very privileged and with much interest.

I knew that my mother had grown up fatherless and poor through the Depression years in a boarding house in Spring Hill Brisbane, having lost her father at sea during a cyclone in the Torres Straits in 1923 when she was one of three children less than five years of age. Because Alice and my mother were very close in age, I had no particular expectations of difference. As a widow alone, my mother's family was vulnerable. Her mother took in washing which my mother and sisters had to walk the streets to collect and then return. Her childhood memories of these experiences were of fear, hardship, deprivation and emotional anxiety. Her sense of loss and separation from her father became a lifelong family lament passed through her story to her children (myself included) who shared in the loss of a maternal grandfather.

My own story of growing up as one of seven children in a poor Catholic family, often ostracised by distance, religion and monetary circumstances on various farms, shared similarities with some of Alice's stories. Alice's tales of employing home remedies to cope with medical emergencies and making meals 'go round' were part of my childhood and remain common experiences for those who grow up in the bush. However, nothing in my experiences throughout life in twentieth century Australia, either during my childhood or as an adult had prepared me for the honest, raw and brutal accounts of racism, discrimination and inequality that sprang from the pages of Alice's book.

Like most white Australians, I was aware of the media focus on the Stolen Generations, but was complacent about the issue, because (I thought) it had nothing to do with me. The human impact never became a reality until it came to me through the literary voice of Alice Nannup, the 'real' life story of the mother of someone for whom I cared deeply. Despite the economic and emotional hardship which were a reality of my mother's life and those which persisted in my generation through the twin realities of a large family and bush life, the obscurity of 'white privilege' sheltered both generations from the realities of racism which saw Aboriginal children separated from their family, their community, their country and their language. Through Alice's story, a hidden and unpleasant face of the past was revealed to me for the first time through literature; a story revealed many times over in Indigenous literature around the world.

My good friend told me that there was still more to the story, but she had purposely waited to share this knowledge 'until I was ready for it'. Then, she gradually and graciously unfolded the story on a deeper personal and spiritual level, and also from a generational perspective. This, she suggested, gave me time to reflect and allowed me to gain a more nuanced awareness and understanding of the complexities of Indigenous knowledge, Indigenous culture, and Indigenous life. This unfolding enabled me to recognise the gaps and silences within Indigenous narratives that reveal much about the long term impact of racist policies of the twentieth century and fractured a subliminal cultural border. Thanks to the benevolence of 
my good friend, this unfolding became the catalyst for developing a framework for conducting intercultural literary research without borders.

My experience with Alice's book taught me that to understand Indigenous literature in any form requires engagement with the critical voices of Indigenous people and demands respect for Indigenous knowledge. The work of Karen Martin (2003) which describes 'Ways of Knowing, Being and Doing' alludes to the necessity, not just in literary discourses, but throughout academic discourses, for a methodology that engages actively and synchronously with Indigenous viewpoints. Whilst ignorance of Australia's cultural and social history is slowly changing due to increased Indigenous literature and cross-cultural collaborations, there are still generations of readers who have not been exposed to the writing of Indigenous people. Many of these readers have no reason to look beyond the negative literary representations of Indigenous people they encounter or the anonymity of white privilege. As Richard Altick (1967) suggests, people are:

[I]ntimately associated with an emotional response to words and often directly responsible for it, are the images that many words inspire in our minds. The commonist type of image is the visual: that is a given word habitually calls forth a certain picture on the screen of our inner consciousness. ( p. 11)

To continue to cross borders in my literary research, it was necessary to challenge the subliminal negative perceptions of Indigenous people created on the screen of my white consciousness. Rigney's (1997, p.114) assertion that: "cultural assumptions throughout dominant epistemologies in Australia are oblivious of Indigenous traditions and concerns" challenged established frameworks for conducting cross-cultural literary research. To penetrate my 'white' lens and broaden my outlook to the possibility of difference as well as to different possibilities, a methodological approach was adopted to engage Indigenous knowledge shared through the writing voices of Indigenous people. In light of the suggestion of bell hooks and Jackie Huggins (Huggins 1998, 63) that non-Indigenous researchers "trying to decolonise themselves...has been a major problem here, with white women wanting to take shortcuts and not wanting to do the actual work”, a methodological approach using a relational discourse was developed to engage with the critical literary voices of Indigenous people to achieve a more nuanced and balanced (unbiased if possible) perspective on themes, events, places, and scenarios. These voices are vital in contemplating and analysing notions and/or conclusions in relation to the writing of Indigenous people.

This methodology engages synchronously with written Indigenous voices to focus the potential of methodologies to destabilise borders, develop cross-cultural awareness, and ultimately challenge epistemological viewpoints within the research arena. The following is a simplified version of the steps in the framework for a relational discourse (fully described in my Masters Dissertation 2010) to aid in the decolonisation of literary analysis:

1. Using the literary technique of contrast and compare, read novel repeatedly to identify distinguishing features that denote difference and/or similarity or commonality with different cultures.

2. Validate significance of distinguishing features through critical writing voice of Indigenous people to avoid biased conclusions due to the ingrained perceptions and limitations of a 'white' lens, (if possible, ask a cultural mentor, remembering always the need for reciprocity). 
3. Compare and contrast differences and/or similarities or commonalities and generate a list of themes to investigate possible links to, or need for, Indigenous research. These links need to (and can) be validated through the critical writing voices of Indigenous people (and if possible, a cultural mentor.

4. Conduct analysis with ethical consideration for Indigenous knowledge.

5. Write-up findings in reflexive, concise, coherent, and logical manner constantly engaging with the critical voices of Indigenous people.

Use of this methodology as an intercultural approach ensures engagement with the relational voice of Indigenous people within literary discourses. This enables and encourages interaction with Indigenous literature while it activates and imbeds Indigenous knowledge into final research outcomes. This engagement has the potential to highlight critical phenomena of importance to Indigenous people which, because of the subliminal bordered consciousness of the dominant 'white' research lens, may otherwise remain unnoticed and/or unattended.

Indigenous writing contains Indigenous knowledge and as such, deserves a place at the forefront of Australian literature. Anita Heiss, who has created a new genre of 'chic-lit' which is helping to cross literary borders, stated in her interview with Tim Elliott (2012) that her desire as a writer was to "portray the positive stories about Aboriginal people because everyone else is doing a great job with the negatives”. Heiss' statement highlights the social necessity for literary discourses to engage with Indigenous literature that deals with contemporary matters as well as historical facts to override the biased and negative stereotypical representations of yesteryear.

Indigenous fiction in conjunction with Indigenous critical texts can open the pathway for non-Indigenous researchers to engage with Indigenous knowledge through the perspectives and voices of Indigenous people to improve cultural understanding and cross-cultural relations. While much Indigenous writing, including poetry, autobiographical narrative, fiction and critical texts has claimed a space within literary discourses, given the wealth of Indigenous writing now available, more diverse approaches are required across all disciplines to encourage the inclusion of Indigenous literature to enable researchers to cross invisible borders between cultures and enhance intercultural implications for the broader Australian community. Such action would achieve a greater understanding of the cross-cultural complexities of Australian society, help to educate as well as entertain, and stimulate action on research to produce sustainable outcomes for Indigenous communities.

\section{Works Cited}

Altick, RD. Preface to critical reading. 4th Ed. New York : Holt Rinehart and Winston, 1967. Print.

Behrendt, L. "Law stories and life stories: Aboriginal women, the law and Australian society”. Australian Feminist Studies, 2005. 20(47), 245-254. DOI: 10.1080/08164640500090434. Print.

- $\quad$ Home. St. Lucia : University of Qld Press, 2004. Print. 
Bird, Carmel. “An Overview of the presence of Indigenous characters in Australian fiction.” University of Granada. December 2001. Address/Talk. Accessed 4 July 2013. http://www.carmelbird.com/indigenous.htm

Elliott, Tim. Interview: Anita Heiss. Sydney Morning Herald. 7 April, 2012. Web. 4 July 2013.

Grenville, K. The Secret River. Melbourne : The Text Publishing Company, 2005. Print.

Hinkson, M. \& J. Beckett. Eds. An appreciation of difference : WEH Stanner and Aboriginal Australia. Canberra ACT : Aboriginal Studies Press, 2008. Print.

Huggins, J. Sister Girl. St Lucia Qld.: University of Qld Press, 1998. Print.

Keneally, T. The chant of Jimmy Blacksmith. Sydney : Angus \& Robertson, 1972. Print.

Kuttainen, V. “History - The Much Less than Final Frontier...”. Frontier Skirmishes: Literary and Cultural Debates in Australia after 1992. Ed. Russell West-Pavlov \& Jennifer Wawrzinek. Heidelberg : Universitätsverlag Winter GmbH Heidelberg, 2010. 153-168. Print.

McDonald, R. The ballad of Desmond Kale. Milsons Point, NSW: Vintage. 2005. Print.

McNamara, N. The past is the present : a cross-cultural exploration of the literary displacement of Indigenous people using a relational discourse (Masters Dissertation), James Cook University, Townsville, Australia. 2010. Print.

Martin, K. "Ways of knowing, being and doing: A theoretical framework and methods for Indigenous and Indigenist re-search.” Journal of Australian Studies, 76 (2003) 203214. Print.

Miller, A. Journey to the Stone Country. Crows Nest NSW : Allen \& Unwin, 2002. Print.

Moore, B. Ed. The Australian Pocket Oxford Dictionary, $5^{\text {th }}$ Edition. Melbourne, Vic : Oxford University Press, 2002. Print.

Nannup, A. When the Pelican Laughed. Fremantle, WA: Fremantle Arts Centre Press, 1992. Print.

O’Conner, E. Spirit Man. Sydney : Angus \& Robertson, 1980. Print.

Prichard, K.S. Coonardoo: The well in the shadow. Penrith : The Discovery Press, 1929/1972. Print.

Reynolds, H. The other side of the frontier. North Queensland : James Cook University. 1981. Print.

Reynolds, H. Dispossession: Black Australians and white invaders. North Sydney, NSW: Allen \& Unwin Pty Ltd, 1989. Print. 
Reynolds, H. Why weren't we told? : A personal search for the truth about our history. Ringwood Vic : Viking, 1999. Print.

Reynolds, H. Nowhere people. Victoria : Penguin Group, 2005. Print.

Rigney, L. "Internationalisation of an Indigenous anti-colonial cultural critique of research methodologies: A guide to indigenist research methodology and its principles.” Journal for Native American Studies, [WICAZO sa Review, University of Minnesota Press] 14(2) (1997) [Fall Ed]: 109-121. Print.

Scott, K. That Deadman Dance. Sydney NSW : Pan Macmillan Australia Pty. Limited, 2010. Print.

Walker, K. My People. 4th Ed. Milton : Jacaranda Press, 1981. Print.

White, P. A Fringe of Leaves. London : Jonathon Cape, 1976. Print.

- Voss: a novel. New York : Viking, 1957. Print. 